\title{
The Perspective of Pregnant Women of Male Student Nurses in Obstetrics and Women's Health Nursing
}

\author{
Gülden Aynacı
}

Trakya University, Obstetrics and Gynecology, Edirne, Turkey

Gülden Aynacı, Dr. Öğr. Üyesi

\section{Correspondence:}

Dr. Öğr. Üyesi Gülden Aynacı

Trakya University, Obstetrics and Gynecology, Edirne, Turkey

Phone: +90 5079799506

E-mail: guldenaynaci@hotmail.com

Received : August 20,2019

Revised : November 04, 2019

Accepted : November 04, 2019

\section{ABSTRACT}

Purpose: It is seen that male student nurses encounter gender-based barriers during their professional experiences. Our aim was to evaluate the perspective of pregnant women of male students in the maternity clinic.

Methods and Materials: The study was conducted March 2019- August 2019 with 421 volunteer pregnant women in the Perinatology Clinic of Trakya University Hospital. The sociodemographic characteristics of the pregnant women were recorded. In order to evaluate the perspectives of the pregnant women of male student nurses, 30 questions consisting of three parts were asked.

Results: When asked whether male nurses should work in maternity wards, $61.99 \%$ of the pregnant women answered ' $n 0$.' When asked whether male students should participate in active maternal and neonatal care in maternity wards, $60.09 \%$ of pregnant women said 'No.' Three-quarters (77.67\%) of the pregnant women thought that male student nurses could communicate easily with their husbands, and $71.49 \%$ believed their husbands would feel more comfortable with male nurses outside the delivery room.

Conclusion: Our study contributed to a better understanding of the approach to male student nurses in obstetrics clinics. As a result of Turkey's cultural structure, male students face gender-based prejudices. Changing the social environment in nursing is a difficult process to influence the value judgments of society. We may not have enough time to change the perspective of societies, it may take many years. Students should be encouraged to become nurses who are professionals. Socioculturally equipping student nurses and making them resistant to psychological attrition will encourage them to perform their profession through ownership.

Keywords: Male student nurses, pregnant women, gender discrimination

\section{GEBELERIN PERSPEKTiFINDEN, KADIN SAĞLIĞI VE HASTALIKLARI HEMŞIRELIĞi'NDE, ERKEK ÖĞRENCILERE BAKIŞ}

ÖZET

Amaç: Erkek hemşirelik öğrencilerinin, mesleki deneyimleri sırasında cinsiyete dayalı engellerle karşıllaştıkları görülmektedir. Amacımız, doğum kliniğinde erkek öğrencilere gebelerin bakış açısını değerlendirmektir.

Yöntem: Çalışmamız Mart 2019-Ağustos 2019'da, Trakya Üniversitesi Hastanesi Perinatoloji kliniğinde interne edilen 421 gönüllü gebeyle yapıldı. Gebelere sosyodemografik özellikleri ve erkek hemşirelik öğrencilerine bakış açlarını değerlendirmek üzere, üç bölümden oluşan 30 soru soruldu.

Bulgular: Erkek hemşireler doğum servislerinde çalışmalı mı sorusuna; gebelerin \%61.99'u hayır cevabını verdi. Doğum servislerinde aktif maternal ve yenidoğan bakımlarına katılmalı mı sorularının cevaplarıysa \%60.09"hayır"dı. Erkek öğrencilerin; doğum servislerinde, diğer gebelerden tepki alacağını düşünenlerin oranı \%78.14, gebelerin eşlerinden tepki alacağını belirtenler \%77.90'dı. Gebelerin \%77.67'si eşlerinin; erkek hemşirelik öğrencilerine, babalara düşen maternal ve yenidoğan bakımıyla ilgili sorularda, daha kolay iletişim kurduklarıı belirttiler. Gebelerin $71.49 \%$ 'u doğum sırasında, doğumhane dışında bekleyecek babaların, yanlarında erkek hemşireler olursa, kendilerini güvende hissedeceklerini belirtti.

Sonuçlar: Bu çalıșma, doğum kliniklerindeki erkek hemşirelik öğrencilerine yaklaşımın daha iyi anlașılmasına ve karşılaștıkları engelleri gebelerin bakış açısılla görebilmemize katkı sağladı. Türkiyénin sosyokültürel yapısının sonucu olarak; erkek öğrencilerin cinsiyete dayalı önyargılarla karşılaşılıı̆ını gösterdi. Kadın sağlığı ve hastalıkları hemşireliği bakım hizmetleri için kadın hemşireler tercih edilmektedir. Toplumda, sosyal ortamın değiştirilmesi, toplumun değer yargılarına etki edilebilmesi zor bir süreçtir. Toplumların bakış açııııın değişmesi için sürecek uzun yıllar için, yeterli zamanımız olmayabilir. Hemşirelik öğrencilerini; sosyokültürel donanımlı, manevi yıpranmalara dayanıkl;; mesleği sahiplenen hemşireler olarak yetişmelerine destek olunmalıdır.

Anahtar sözcükler: Erkek hemşirelik öğrencileri, doğum klinikleri, gebe, cinsiyet ayrımcılı̆ı 
tudies have shown that male nurses face gender barriers during their health professional experiences. Despite the continuing innovations affecting healthcare, the gender imbalance in the nursing profession remains. Women account for $96 \%$ of all employees in general nursing life. The proportion of women in psychiatric nursing falls to $70 \%$, whereas it can increase to more than $96 \%$ in obstetrics and gynaecology nursing (1).

Since the beginning of modern nursing, it has been noted that the image of a 'good nurse' cannot be distinguished from that of a good woman or a good mother. Presumably, this perception is still present (2). It is inextricably linked to the perception that the ability to provide care to patients is a feminine attribute and therefore not a masculine-related trait.

Research on the experiences of male student nurses has emerged recent years (3). The most common problem of male student nurses in studies is that they are not fully accepted as nurses. It is stated that professional employees in the health service are treated differently from female students and are not offered equal learning opportunities. Male nursing students state that as the second problem, they are considered first for jobs that require physical force (4). They state that they are the first to come to mind when they need to go to a remote place and in jobs that require physical strength, such as moving patients and heavy materials. In addition, male students are prevented from participating in interventions when female patients are required to be cared for. Health workers have stated that this blocking is not an individual case with male students, but it is not appropriate for male students to intervene in female patients. This results in male students being unable to gain adequate educational experience. However, in most health centers, it is no problem for female students to take care of male patients (5). Male student nurses in obstetrics and gynecology clinics are not well received by employees and are unable to take an active role in patient care (6).

\section{Aim}

Male nursing students are seen to face gender barriers during their professional experiences. Our goal was to evaluate the point of view of pregnant women in regard to male students in the maternity clinic.

\section{Methods and materials}

Type of research

This is a descriptive research.
Where the research was conducted

The study was conducted between August 2018 and July 2019 in the Perinatology clinic of the Department of Obstetrics and Gynecology of Trakya University Medical Faculty Hospital.

\section{Population and sampling}

The population of the research was composed of pregnant women aged 18-45 years who were hospitalized between March 2019 and August 2019 in the Perinatology clinic of the Department of Obstetrics and Gynecology of the Trakya University Faculty of Medicine, Health Practice and Research Center Hospital. The universe of this study was the pregnant women that had been hospitalized in perinatology clinics in Turkey. During the study period, our study was completed with 421 volunteer pregnant women who had no psychological illness, who were willing to participate in the study, and who answered all the questions. The participants were informed about the study and each gave voluntary written consent.

\section{Data collection}

In addition to sociodemographic features, the pregnant women were asked 30 questions in three parts through face-to-face interviews. In the first section, including 16 questions and in the second section including 7 questions, answers as "yes" and "no" were received. In the third section, the women were asked to choose between male and female nurses in accordance with the 7 questions asked.

\section{Evaluation of data}

All statistical analyses were performed using the SPSS 20.0 package program. The data were summarized with the appropriate descriptive statistics. For numerical variables, mean and standard deviation are given, and for categorical variables, descriptive statistics are given as frequency and percentage. In all statistical analyses, the level of significance was determined as $5 \%$.

\section{Limitations of the research}

Our study had some limitations. It should be taken into account that mothers' mental health needs are often sought and provided by women. Our research found no answer to the question of how reproductive health services would be affected by a greater focus on fathers. More studies can be done on this subject. Because fathers were not included in this study, their views were not taken. Different studies can be done in which the opinions of the husbands of pregnant women are taken. 


\section{Ethics committee approval}

For our study, ethics approval was obtained from the Scientific Research Ethics Committee of Trakya University Faculty of Medicine (Decision No: 22121724-050.04.02 E.312935).

\section{Results}

In the study, 421 volunteers participated. Of the pregnant women, 233 were hospitalized for the first time, 188 pregnant women were hospitalized in the obstetrics service in their previous pregnancies or in this pregnancy.

\section{Sociodemographic characteristics of participants}

The mean age of the volunteers was 29.39 (range, 1838) years. Of the 421 pregnant women, 159 (37.76\%) had their first pregnancy, 104 (24.70\%) had their second pregnancy, $84(19.95 \%)$ had their third pregnancy, and $74(17.57 \%)$ had their fourth or subsequent pregnancy. They were asked about their professions; according to their answers, 104 (24.70\%) were working in a permanent job, 316 (75.05\%) did not work in a job for which they received regular salaries over the past 1 year. Their families' hometowns were divided into 3 geographic regions. The number of pregnant women who came from western regions, eastern regions, and Central Anatolia and the central Black Sea region was 215 (51.06\%), 97 (23.04\%), and $109(25.89 \%)$, respectively.
In the first part of the study, we aimed to evaluate the perspective of pregnant women in regard to male nurses and male student nurses. The first section consisted of 16 questions. Four hundred and nine pregnant (97.14\%) women specified that male nurses were eligible to work in emergency departments and $94.77 \%$ of considered that male nurses were eligible to work in the surgical operating room. However, when we asked if male nurses should work in maternity wards, 261 pregnant women (61.99\%) answered "no." When questioned about whether male nurses should participate in active maternal and neonatal care in maternity services, the answer was also "no" for 253 (60.09\%) pregnant women.

The majority $(78.14 \%, \mathrm{n}=329)$ of pregnant women thought that male student nurses would get a negative reaction from pregnant women and $77.90 \%(n=328)$ said that they would get a negative reaction from the husbands of pregnant women.

Forty-one percent $(41.80 \%, \mathrm{n}=176)$ of the pregnant women stated that they would not react negatively to being trained by male nurses in terms of postpartum breastfeeding. Almost half ( $n=202,47.98 \%$ ) of the pregnant women responded "no" to the question "When you give birth to a baby, would you like a male nurse to provide maternal and newborn care?"

\section{Table 1. General approach of pregnant women to male student nurses}

\begin{tabular}{|c|c|c|}
\hline The perspective of pregnant women in regard to male nurses and male student nurses & $\begin{array}{c}\text { YES } \\
n(\%)\end{array}$ & $\begin{array}{c}\text { NO } \\
n(\%)\end{array}$ \\
\hline Male nurses were eligible to work in emergency departments & $409(\% 97.14)$ & $12(\% 2.86)$ \\
\hline Male nurses were eligible to work in the surgical operating room & $395(\% 93.82)$ & $26(\% 6.18)$ \\
\hline male nurses should work in maternity wards & $160(\% 38.01)$ & $261(\% 61.99)$ \\
\hline male nurses should participate in active maternal and neonatal care in maternity services & $168(\% 39.91)$ & $253(\% 60.09)$ \\
\hline male student nurses would get a negative reaction from pregnant women & $329(\% 78.14)$ & $92(\% 21.86)$ \\
\hline male student nurses would get a negative reaction from the husbands of pregnant women & $93(\% 22.10)$ & $328(\% 77.90)$ \\
\hline Male student nurses would not react negatively to being trained by male nurses in terms of postpartum breastfeeding & $176(\% 41.80)$ & $245(\% 58.20)$ \\
\hline When you give birth to a baby, would you like a male nurse to provide maternal and newborn care & $202(\% 47.98)$ & $219(\% 52.02)$ \\
\hline Pregnant women thought that male nurses could not help at the time of vaginal delivery. & $179(\% 42.52)$ & $242(\% 57.48)$ \\
\hline It was not appropriate for the preparation to be made by a male nurse so that the male/female obstetrician could examine & $205(\% 48.69)$ & $216(51.31 \%)$ \\
\hline The pregnant women who did not want male nurses to assist in postpartum dressing and wound care & $256(\% 60.81)$ & $165(\% 39.19)$ \\
\hline The pregnant women who indicated that they would not give approval for urogenital care & $142(\% 33.73)$ & $279(\% 66.27)$ \\
\hline They would not allow male nurses or male student nurses to give breast care education, even if it was verbal & $173(\% 41.10)$ & $248(\% 58.90)$ \\
\hline The pregnant women who stated that it was appropriate for male nurses to work in neonatal units & $305(\% 72.44)$ & $116(\% 27.56)$ \\
\hline They thought that male nurses could provide premature infant care & $316(\% 75.05)$ & $105(\% 24.95)$ \\
\hline They could comfortably ask male nurses and male student nurses questions about postpartum ma & $162(\% 38.48)$ & $259(\% 61.52)$ \\
\hline
\end{tabular}


Two hundred forty-two (57.48\%) pregnant women thought that male nurses could not help at the time of vaginal delivery. The number of those who stated that it was not appropriate for the preparation to be made by a male nurse so that the male/female obstetrician could examine was 216 (51.31\%).

The number of pregnant women who did not want male nurses to assist in postpartum dressing and wound care was 256 (60.81\%). The number of pregnant women who indicated that they would not give approval for urogenital care was 279 (66.27\%).

Among the pregnant women, the proportion of those who stated that they would not allow male nurses or male student nurses to give breast care education, even if it was verbal, was $58.90 \%(n=248)$.

The proportion of pregnant women who stated that it was appropriate for male nurses to work in neonatal units was $72.44 \%$ ( $n=305)$. Three-quarters $(75.05 \%, n=316)$ thought that male nurses could provide premature infant care.

The proportion of pregnant women who stated that they could not comfortably ask male nurses and male student nurses questions about postpartum maternal care at home was $61.52 \%(n=259)$.

In the second part of the study, the observations of pregnant women were evaluated. This section consisted of 7 questions. Based on their observations, the pregnant women were asked whether male student nurses had been subjected to gender discrimination in the maternity wards. The majority $(79.80 \%, \mathrm{n}=336)$ stated that they had received health care from male student nurses when they were hospitalized. The women were asked if female nurses helped male student nurses in the practice areas and $76.95 \%$ ( $n=324)$ said that they had witnessed female nurses helping.

Our study continued with issues related to the husbands of the pregnant women. Three-quarters of the women $(77.67 \%, \mathrm{n}=327)$ stated that their husbands would communicate more easily with male nurses and male student nurses about their part of maternal and neonatal care and would be less timid towards them. Seventy-one percent of the pregnant women $(71.49 \%, n=421)$ thought that the fathers, who were on stand-by outside the maternity ward, would feel comfortable with male nurses and would share their feelings more easily with them.

The pregnant women were asked as to whether their partners would prefer male nurses or male student nurses to help delivery; 310 (73.63\%) answered "no." The women were asked whether their relatives would voluntarily choose male nurses to help for delivery, 157 (37.29\%) said that they would not. When they were asked, "When giving birth, would you prefer a male doctor," $51.06 \%(n=215)$ of them answered "yes."

The third part comprised 7 questions. In this part, the perceptions of pregnant women on differences between male and female nurses were addressed. They were asked to choose between male and female nurses according to the questions.

One hundred forty-three (33.96\%) of the pregnant women thought that male nurses had less physical difficulty during night shifts, and 161 (38.24\%) believed that male and female nurses had similar physical difficulty during night shifts.

Table 2. Observations of pregnant women

\begin{tabular}{|c|c|c|}
\hline Observations of pregnant women & $\begin{array}{c}\text { YES } \\
n(\%)\end{array}$ & $\begin{array}{c}N 0 \\
n(\%)\end{array}$ \\
\hline The pregnant women had received health care from male student nurses when they were hospitalized & $336(\% 79.80)$ & $85(\% 20.2)$ \\
\hline $\begin{array}{l}\text { The women were asked if female nurses helped male student nurses in the practice areas and said that } \\
\text { they had witnessed female nurses helping. }\end{array}$ & $324(\% 76.95)$ & $97(\% 23.05)$ \\
\hline $\begin{array}{l}\text { The women stated that their husbands would communicate more easily with male nurses and male } \\
\text { student nurses about their part of maternal and neonatal care and would be less timid towards them }\end{array}$ & $327(\% 77.67)$ & $94(\% 22.33)$ \\
\hline $\begin{array}{l}\text { The pregnant women thought that the fathers, who were on stand-by outside the maternity ward, would } \\
\text { feel comfortable with male nurses and would share their feelings more easily with them. }\end{array}$ & $300(\% 71.25)$ & $121(\% 28.75)$ \\
\hline $\begin{array}{l}\text { The pregnant women were asked as to whether their partners would prefer male nurses or male student } \\
\text { nurses to help delivery }\end{array}$ & $111(\% 26.37)$ & $310(\% 73.63)$ \\
\hline The women were asked whether their relatives would voluntarily choose male nurses to help for delivery & $264(\% 62.71)$ & $157(\% 37.29)$ \\
\hline "When giving birth, would you prefer a male doctor" & $215(\% 51.06)$ & $206(\% 48.94)$ \\
\hline
\end{tabular}




\begin{tabular}{|c|c|c|c|}
\hline male nurses were addressed & Female nurse & Male nurse & No difference \\
\hline The pregnant women thought that male nurses had less physical difficulty during night shifts & $117(\% 27.8)$ & $143(\% 33.96)$ & $161(\% 38.24)$ \\
\hline $\begin{array}{l}\text { The pregnant women stated that male nurses could make patient care easier with the advantage of } \\
\text { muscle strength compared with female nurses }\end{array}$ & $96(\% 22.82)$ & $183(\% 43.46)$ & $142(\% 33.72)$ \\
\hline $\begin{array}{l}\text { The pregnant women were asked whether female nurses or male nurses were more patient toward } \\
\text { patients.angi hemşireler doğum servisinde hastalara daha sabırlı davranır? }\end{array}$ & $129(\% 30.64)$ & $107(\% 25.41)$ & $185(\% 43.94)$ \\
\hline $\begin{array}{l}\text { The pregnant women were asked whether male or female nurses were more gentle to the partners of } \\
\text { pregnant women }\end{array}$ & $70(\% 23.61)$ & $209(\% 49.64)$ & $142(\% 33.72)$ \\
\hline $\begin{array}{l}\text { The pregnant women were asked whether there were differences between female and male nurses in } \\
\text { terms of communication established with patients in maternity services }\end{array}$ & $185(\% 43.94)$ & $70(\% 16.62)$ & $127(\% 30.16)$ \\
\hline $\begin{array}{l}\text { The pregnant women in maternity services were asked which group (female or male nurses) they } \\
\text { would allow to provide care when their mother or aunt became ill. The number of those who allowed } \\
\text { female nurses more easily }\end{array}$ & $228(\% 54.15)$ & $24(\% 5.70)$ & $169(\% 40.14)$ \\
\hline The patients' relatives were asked whether female or male students were more patient. & $88(\% 20.90)$ & $52(\% 12.35)$ & $281(\% 66.74)$ \\
\hline
\end{tabular}

Forty-three percent of the women $(43.46 \%, n=183)$ stated that male nurses could make patient care easier with the advantage of muscle strength compared with female nurses, whereas 142 (33.72\%) thought that there was no difference in muscle strength needed in patient care for male and female nurses.

Pregnant women were asked whether female nurses or male nurses were more patient toward patients. Of the pregnant women, 30.64\% $(n=129)$ answered "female nurses," $25.41 \%(n=107)$ answered "male nurses," and $43.94 \%$ ( $n=185)$ answered "no difference between them."

We asked whether male or female nurses were more gentle to the partners of pregnant women, 142 (33.72\%) answered as "both female and male nurses," 70 (23.61\%) answered "female nurses," and 209 (49.64\%) thought that male nurses were more gentle to the partners.

Pregnant women were asked whether there were differences between female and male nurses in terms of communication established with patients in maternity services; 185 (43.94\%) answered "female nurses" had better communication and 70 (16.62\%) answered "male nurses." One hundred twenty-seven (30.16\%) said that they saw no difference in terms of communication between male and female nurses.

Pregnant women in maternity services were asked which group (female or male nurses) they would allow to provide care when their mother or aunt became ill. The number of those who allowed female nurses more easily was $54.15 \%$ $(n=228)$, whereas the number of those who would allow male nurses more easily was $5.70 \%(n=24)$; the number of those who stated that they would allow both female and male nurses to give care was $40.14 \%(n=169)$.

The patients' relatives were asked whether female or male students were more patient. Of them, 281 (66.74\%) stated that both female and male students were understanding and patient, $52(12.35 \%)$ said that male students were more understanding and patient, and 88 (20.90\%) reported that female students were more understanding and patient.

\section{Discussion}

Although peripartum and postpartum studies are largely focused on mothers, there is growing literature about the needs and concerns of fathers during this period (7). It would be easier for fathers to share their paternity concerns with male nurses or male nursing students. The fact that fathers feel spiritually secure will allow them to more easily understand their partner's needs during the peripartum and postpartum period. Confident and conscious fathers will also contribute to the well-being of mothers and newborns. Our study shows that male nursing students will more comfortably support fathers and share information with them.

Research is continuing for the prenatal, natal, and postnatal periods. Results show that positive paternal health improves the general health of the family and more resources are needed for fathers who demand information (8). In the studies, it was stated that the women with low education level had more negative opinions towards male nurses (9). In our study, we found that the pregnant 
women did not prefer male nurses and nursing students; however, the reaction of the women to male student nurses was not as severe as we expected.

There is growing criticism that pre-and post-natal services are always targeting mothers, but fathers also need help to prepare for parenthood. From a logistical point of view, the proportion of male nurses varies internationally but is generally low in the world (10). Many studies stress that fathers cannot feel comfortable discussing their concerns with female medical staff in maternity wards (11). Recognizing the needs of fathers also raises the question about who would be the best source of information for fathers. It is clear that fathers would be more comfortable to receive these services from male nurses. However, increasing the numbers of male nurses in maternal and fetal health services also brings its own challenges. It is important to note that the protection and development of maternal and fetal health is at the forefront in all cases.

The pregnant women in our study indicated that they preferred female nurses in maternity wards to give them preand post-natal care. The proportion of pregnant women who allowed male student nurses to enter the maternity ward was $26.37 \%$. However, the partners of pregnant women thought that they could easily exchange information with male nurses at the time of birth outside the maternity ward and during the postpartum period.

Fathers also have a number of duties. Inadequate knowledge of the duties of fathers can cause neglect of mother and baby after returning home. Previous research has shown that the attention and sensitivity of fathers varies according to the sex of the healthcare provider (12). Pregnant women need more attention from their partner, especially during the last trimester of pregnancy. Our data showed that if their partners could communicate with male nurses, they would feel more comfortable. However, we still found that conservative concerns arising from the traditions of Turkish society persisted. There were a majority of pregnant women who thought their partners would definitely not be interested in receiving health care from male nurses.

In research with male student nurses in the United States, most of the participants noted that male students worked harder. They reported that male students were more disciplined than female students, and that male students were more comfortable in patient care that required strength. However, they said that male students often faced more strenuous work. Similarly, in an Irish study, rotations in obstetric nursing were much more difficult for male students than other clinical rotations. In addition, male participants noted that they were less involved in practices than female nursing students, but were deemed valuable for their physical strength $(13,14)$. Male students reported in some studies that they were pushed out of the nursing group and that they were even offered a profession other than nursing. Some male students reported concern that they would be charged with sexual impropriety or even with sexual assault while providing special care to female patients. Male nursing students reported that this anxiety decreased after graduation; however, it remains an important source of stress for students (15). Some participants stated that they chose this profession and did not care about the problems (16). Simulation and training for women's health and diseases and maternity nursing offers male student nurses a different alternative to their obstetric clinical practice. With simulation training, and with the provision of more practice in clinics, the confidence of student nurses can be increased. The university in which the male nursing student is trained forms the basic structure in reducing or preventing problems.

Male nurses working in the obstetrics and gynecology unit often face difficulties (7). We found that discrimination and bias towards male nurses and male students were among the main causes of these difficulties.

Clinical instructors, academics at universities, nurses working in the field, managers of health institutions, experts at all stages of health service delivery should assist in maintaining gender equality in clinics. Nursing care is among the main fundamental elements in the protection of prenatal, maternal, and fetal health, and in the development of maternal and neonatal health after childbirth. The aim of health presentation should be to address the family as a mother, father, and child, and it is concluded that the service to the fathers will also bring benefits for the mother and child (17). In the studies, it is recommended to increase the number of male nurses in the study fields, to introduce the nurses and nursing profession to the society, and to raise the awareness that nursing is not only a woman profession (9). In order to provide quality healthcare internationally, first, it is necessary to eradicate gender discrimination and bias against male student nurses. Some strategies can be used for this. One of the most important approaches is to fulfill the wishes of women who may be uncomfortable in the presence of a male nurse. The value judgments of society should be respected; however, in the provision of health services, male student 
nurses should not be deprived of the support required in the practices and clinics such that society may become accustomed to their presence.

Today, women are able to choose male obstetricians and gynecologists for examination and treatment (18). Male student nurses can take their place within maternity and women's health nursing. Maternal mental health is arguably crucial. Nevertheless, it is important to acknowledge that the perinatal period is also stressful for fathers. Fathers can communicate more comfortably with male nurses because they are of the same sex.

\section{Conclusion}

This study contributes to a better understanding of the approach to male student nurses in practice in maternity clinics. It allows us to see the obstacles that male students face in their social lives and practice from the perspective of pregnant women. The findings show that as a result of the sociocultural structure of Turkey, male students face gender bias during maternity and obstetrics nursing practices. The findings suggest that male student nurses, in the face of challenges, can act positively.

In addition to education, multiple support mechanisms and enabling students to live positive experiences in nursing degree programs will help nurses manage negative factors in both their practice and social lives and grow as capable individuals who can think positively. Changing

\section{References}

1. Keogh B, O'Lynn C. Male nurses' experiences of gender barriers: Irish and American perspectives. Nurse Educ. 2007;32:256-9. [CrossRef]

2. Chesler P. Women and madness: Chicago Review Press; 2018.

3. Stott A. Issues in the socialisation process of the male student nurse: implications for retention in undergraduate nursing courses. Nurse educ today. 2004;24:91-7. [CrossRef]

4. Aynacı G, Gulmez H. Looking at Male Nurse Discrimination among Nursing Students with O'Connor Finger-Dexterity Test. J Men's Health. 2019;15:e30-e9. [CrossRef]

5. Hung CA, Wu PL, Liu NY, Hsu WY, Lee BO, Pai HC. The effect of genderfriendliness barriers on perceived image in nursing and caring behaviour among male nursing students. J Clin nurs. 2019;28:146572. [CrossRef]

6. Zahid AZM, Ismail Z, Abdullah B, Daud S. Gender bias in training of medical students in obstetrics and gynaecology: a myth or reality? Euro J Obstet Gynecol Reprod Biol. 2015;186:17-21. [CrossRef]

7. Newham JJ, Alderdice F. If gender matters in maternity care, does it matter in maternity care research? J Reprod Infant Psychol. 2017;35:209-11. [CrossRef] the social environment in nursing is a difficult and slow process that can affect the value judgments of society. It takes many years for the perspective of societies to change, and we may not have enough time for that. Training nursing students as socioculturally equipped and making them resistant to psychological attrition will encourage them to perform their profession through ownership.

Nursing is becoming increasingly diverse and must meet the needs of the changing population. Academics in the field of nursing should be resolute in their efforts to reduce gender bias. Male student nurses should be supported in cases of gender bias during applications and efforts should be made for constructive solutions.

We would like to draw the attention of educators, who should understand the difficulties male nursing students face, should provide them with appropriate support and should find solutions for male students so that they are not left in the background in special areas such as obstetrics service. In addition, university students should be made aware of the available support systems. It is important for male student nurses to be introduced to role models who can help them stay in nursing and make their contribution in working environments.

\section{Acknowledgements}

I want to thank to Ass. Prof. Dr. Selçuk Korkmaz for statical evaluation.
8. Darwin Z, Galdas P, Hinchliff S, Littlewood E, McMillan D, McGowan $\mathrm{L}$, et al. Fathers' views and experiences of their own mental health during pregnancy and the first postnatal year: a qualitative interview study of men participating in the UK Born and Bred in Yorkshire (BaBY) cohort. BMC Pregnancy Childbirth. 2017;17:45. [CrossRef]

9. Çelik As, Pasinlioğlu T, Çilek M, Çelebi A. Kadın Doğum Servislerinde Yatan Hastaların Erkek Hemşireler Hakkındaki Düşüncelerinin Belirlenmesi. Anadolu Hemşirelik ve Sağlık Bilimleri Dergisi. 2012;15:254-61.

10. Aiken LH, Sloane DM, Bruyneel L, Van den Heede K, Sermeus W, Consortium Rc. Nurses' reports of working conditions and hospital quality of care in 12 countries in Europe. Int J Nurs Stud. 2013;50:14353. [CrossRef]

11. Deave T, Johnson D, Ingram J. Transition to parenthood: the needs of parents in pregnancy and early parenthood. BMC Pregnancy Childbirth. 2008;8:30. [CrossRef]

12. Alden KR, Lowdermilk DL, Cashion MC, Perry SE. Maternity and women's health care-E-book: Elsevier Health Sciences; 2013.

13. Begley CM. Great fleas have little fleas': Irish student midwives' views of the hierarchy in midwifery. J Adv Nurs. 2002;38:310-7. [CrossRef] 
14. Kouta C, Kaite CP. Gender discrimination and nursing: a literature review. J Prof Nurs. 2011;27:59-63. [CrossRef]

15. MacWilliams BR, Schmidt B, Bleich MR. Men in nursing. AJN The Am J Nurs. 2013;113:38-44. [CrossRef]

16. Shin G, Kim S, Lee YK. Experiences of Male Nursing Students in Simulation Training for Maternal and Child Nursing Care. Clin Simulation in Nurs. 2017;13:95-101. [CrossRef]
17. Finlayson K, Downe S, Vogel JP, Oladapo OT. What matters to women and healthcare providers in relation to interventions for the prevention of postpartum haemorrhage: a qualitative systematic review. PloS one. 2019;14:e0215919. [CrossRef]

18. Amir H, Abokaf H, Levy YA, Azem F, Sheiner E. Bedouin women's gender preferences when choosing obstetricians and gynecologists. J immigr minor health. 2018;20:51-8. [CrossRef] 